\title{
TOOTH FRACTURE EVALUATION AND ENDODONTIC TREATMENT IN DOGS
}

\author{
I. CAPÍK, V. LEDECKÝ, A. ŠEVČÍK \\ Department of Surgery, University of Veterinary Medicine, Košice, Slovak Republic
}

\author{
Received September 19, 1999 \\ Accepted May 31, 2000
}

\section{Abstract}

Capík I., V. Ledecký, A. Ševčík: Tooth Fracture Evaluation and Endodontic Treatment in Dogs. Acta Vet. Brno 2000, 69: 115-122.

Tooth fractures constitute a considerable fraction of all tooth diseaes. Out of 5370 dogs treated during four years, $492(9 \%)$ patients were treated for dental problems. Out of this number, 139 $(28.3 \%)$ dogs were treated for tooth fractures. The most frequently affected teeth were canines, 54 cases $(38.8 \%)$ succeeded by 46 premolar teeth $(33.1 \%), 36$ incisors $(25.9 \%)$ and 3 molars $(2.2 \%)$. From among the patients with canine and incisor fractures, $61(67.7 \%)$ were large breed dogs. Frontal teeth fractures occurred during training, guard and police work or in play. On the other hand, the premolar fractures (especially 108, 208) were divided evenly among large and medium (small) breeds.

The results of nonsurgical endodontic treatment showed $100 \%$ success with incisors and canines. Periapical lesions were seen infrequently in the above-mentioned teeth. Out of 24 endodonticaly treated incisors and canines with necrotic pulp the periapical lesions were present only in 3 cases $(12.5 \%)$

Fractures of upper fourth premolars were divided evenly among large ( 15 dogs with 18 fractures), medium (small) breeds ( 21 dogs with 23 fractures). Higher incidence of crown damage (fracture line reaching subgingival tooth portion) was observed in large breed dogs $(82.3 \%)$ as compared to medium and small breeds $(37.5 \%)$. X-ray examinations showed a high number of periapical lesions (37 - 90.2\%). The distal root alone was involved in 20 teeth $(48.8 \%)$. Radiolucencies in distal and mesial regions were observed in 11 teeth $(26.8 \%)$. The mesial region was involved in 6 teeth $(14.6 \%)$.

All patients without local complications (swelling, fistula) were treated successfully $(100 \%)$. Out of 12 cases accompanied with local complications ( 4 swellings, 8 fistulas) failure was recorded in 4 cases $(33.3 \%)$. The fistulas were closed within one week. Despite a considerable incidence of root lesion the results of standard endodontic treatment were good. Standard root canal therapy, performed repeatedly following a relapse, yielded mostly good therapeutic results.

Fistula, swelling, age, breeds, periapical lesions

Tooth fractures occurring predominantly as crown and cup fractures, or buccolingual (palatolingual) slab fractures, are common diagnosis in veterinary dentistry.

According to Eisenmenger and Zetner (1985), and Harvey and Emily (1993), the prevalence of tooth fractures is influenced by two factors:

- anatomical position and the height of the tooth

- the use and activity of dogs

The diagnosis of endodontic lesions in veterinary dentistry is complicated by the lack of diagnostic procedures based on subjective symptoms of pain, sensitivity to hot, cold, or percussion, and foul taste or odour.

Holmberg (1979) described pain symptoms in dogs such as salivation, holding head aside, and pawing, especially after eating. Schmeltzer et al. (1980) did not observe any clinical signs of pain with pulp-affected tooth fractures.

The majority of tooth fractures are accompanied by open pulp cavity and other associated complications. The inflammatory process, progressing via apical delta, results in periapical inflammation. Franceschini (1974) and Neuman (1988) consider the fourth maxillary

Address for correspondence:

MVDr. Igor Capík, PhD.

Department of Surgery

Komenského 73,041 81 Košice, Slovak Republic
Phone: + 421956229924

E-mail: capik@uvm

http://www.vfu.cz/acta-vet/actavet.htm 
premolars the teeth most commonly affected by cystic swellings and fistulas. The swelling or fistulas generally occur below the medial eye cantus, especially in older mongrels. These swellings are often described as suborbital (facial) swelling or facial sinus. The fistula may occasionally arise at mucogingival junction.

Rossman et al. (1982) described the possible occurrence of fistula at other teeth. They mention the first maxillary molar and canine teeth, but these fistulas are not as frequent as those at fourth maxillary premolars.

The aim of our study was to evaluate a sample of clinical patients for the following:

- the incidence of tooth fractures in dogs in relation to the age, body size and, in caes of available history, also to the cause.

- the success of standard endodontic therapy.

\section{Materials and Methods}

We present analysis of tooth fractures treated at the Department of Surgery over a four year period, showing prevalence of tooth fractures of incisors, canines, premolars and molars, their relation to age, body size, and location of the fracture line. The investigation was performed on 5370 dogs of different breeds, age and sex. Out of them, 139 cases suffered from tooth fractures.

The evaluated group consisted of clinical patients. Before the treatment, the teeth were examined radiographically to confirm possible periapical lesions.

All tooth fractures with necrotic pulp and in mature teeth with vital pulp were treated by standard root canal therapy:

a/ Making access to the root canal.

b/ Removal of all diseased pulpal content and necrotic dentin.

c/ Irrigation of pulp cavity and root canal with antiseptic agents $\left(3 \% \mathrm{H}_{2} \mathrm{O}_{2}\right.$, retrograde disinfection of periapical tissues and fistulous tract using $0.5-1 \%$ chlorhexidine - Nolvasan, and root canal with sodium hypochlorite Chlordent). The root canals in teeth with fistulas were irrigated under pressure to achieve a passage of antiseptic solution through the fistula.

d/ Drying the canal.

e/ Filling the canal (gutta-percha points, glassionomer cement Ketac - Endo Aplicap).

$\mathrm{f} /$ Restoration of the access site (photocomposits $\mathrm{P}^{50}-3 \mathrm{M}$ ).

$\mathrm{g} /$ Aftercare (antibiotics - clindamycin $10 \mathrm{mg} \cdot \mathrm{kg}^{-1}$ twice daily for at least seven days). Periapical tissues were checked by $\mathrm{X}$ - ray in half-year intervals up to one year after the therapy.

\section{Results}

Tooth fractures are the second most common group of tooth diseases. The prevalence of tooth fractures in incisors, canines, premolars and molars is shown in Table 1. The premolar fractures are divided into fractures of upper carnasial teeth $(108,208)$ and other premolar fractures, the latter ones occurring in small numbers.

Table 1

Prevalence of tooth fractures in dogs

\begin{tabular}{|l|c|c|}
\hline Fractures & Number & $\%$ \\
\hline Incisors & 36 & 25.9 \\
\hline Canines & 54 & 38.8 \\
\hline Premolars $(108,208)$ & 41 & 29.5 \\
\hline Other premolars & 5 & 3.6 \\
\hline Molars $(309,409)$ & 3 & 2.2 \\
\hline
\end{tabular}

The analysis of tooth fractures (Table 2) revealed that incisor and canine fractures occur predominantly in large breeds, especially in working dogs.

Past studies showed that the factures of frontal teeth (incisors, canines) occurred predominantly during training, guard and police work, in play (mouthing/catching thrown objects unsuitable for play - stones, thick tree branches, etc.), and behavioural problems such as chewing foreign objects (Tables 3,4$)$. 
Table 2

The relationship between the size of dogs and tooth fractures

\begin{tabular}{|l|c|c|c|}
\hline Teeth & Large breeds & Medium and small & Toy \\
\hline Incisors & 29 & 7 & - \\
\hline Canines & 48 & 6 & - \\
\hline Premolars & 26 & 20 & - \\
\hline Molars & 5 & 1 & - \\
\hline Total & $105(75.5 \%)$ & $34(24.5 \%)$ & - \\
\hline
\end{tabular}

Table 3

Factors contributing to canine fractures

\begin{tabular}{|l|c|c|}
\hline Cause & Number & $\%$ \\
\hline Trauma & 8 & 14.81 \\
\hline Games & 13 & 24.07 \\
\hline Training & 13 & 24.07 \\
\hline Behaviour problems & 3 & 5.56 \\
\hline Unknown & 17 & 31.48 \\
\hline
\end{tabular}

Table 4

Factors contributing to incisor fractures

\begin{tabular}{|l|c|c|}
\hline Cause & Number & $\%$ \\
\hline Trauma & 11 & 30.56 \\
\hline Games & 10 & 27.78 \\
\hline Unknown & 15 & 41.67 \\
\hline
\end{tabular}

Table 5

Prevalence of four maxillary premolar fractures related to the size of dogs

\begin{tabular}{|l|c|}
\hline Size of dogs & Number of fractures \\
\hline Large & 18 \\
\hline Medium & 17 \\
\hline Small & 6 \\
\hline
\end{tabular}

Table 6

The relationship between tooth fractures and the age of dogs

\begin{tabular}{|l|c|c|c|}
\hline Age & Incisors & Tooth group Canines & Fourth upper premolars \\
\hline up to 2 years & $24^{*}$ & $24^{*}$ & 13 \\
\hline $3-4$ years & $10^{*}$ & $21^{*}$ & 8 \\
\hline $5-6$ years & 2 & 6 & 9 \\
\hline $7-8$ years & 0 & 3 & 3 \\
\hline $9-10$ years & 0 & 0 & 4 \\
\hline $11-13$ years & 0 & 0 & 41 \\
\hline Total & 36 & 54 & 4 \\
\hline
\end{tabular}

$* \mathrm{~F}$ - test significant $(P \leq 0.05)$

It should be noted, that the cause of a considerable number of tooth fractures remained unnoticed by owners. The number of the overlooked tooth fractures of incisors and canines exceeded one third of all fractures $(32$ teeth $=35.5 \%)$. The incisor fractures in maxilla were almost twice as frequent $(21$ teeth $-63.6 \%)$ as those in mandible $(12$ teeth $-36.4 \%)$. 
A reverse situation was observed with canines. Mandibular canine fractures (35 teeth $64.8 \%$ ) were more frequent than the maxillary ones $(19$ teeth $-35.2 \%)$.

Different results were noticed with premolar and molar fractures. These fractures, especially those of upper fourth premolars, were divided equally between large and medium (small) breeds (Table 2).

The occurrence of fractures as related to age is illustrated in Table 6. There is an obvious difference between incisor and canine fractures on the one hand and premolars on the other hand. Altogether 87 incisor and canine fractures $(96.6 \%)$ occurred in dogs during the first six years. The highest number occurred up to two years of age -48 teeth $(53.3 \%)$ and aditional 31 teeth $(34.4 \%)$ up to four years of age. This amounts to altogether $87.7 \%$ of all incisor and canine fractures. Incisor and canine fractures were not found in dogs older than eight years.

Statistical evaluation by the F-test proved significant $(P<0.05,++)$ hyperbolic relationship between the incidence of frontal teeth fractures and the age of patients. Fig. 1 illustrates the

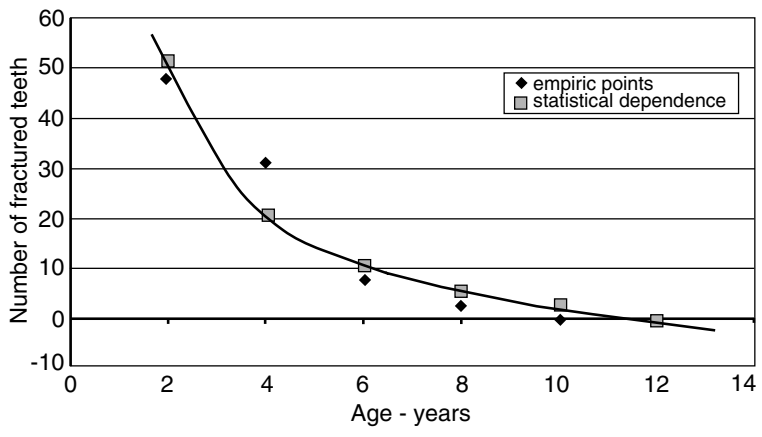

Fig. 1. Incidence of frontal teeth fractures as related to age of dogs relationship between the number of fractured frontal teeth and the age of the affected dogs.

The fourth upper premolar fractures were almost equally distributed among different age categories (Table 6), decreasing slightly with the increasing age of dogs. Statistical evaluation of incidence of fourth maxillary premolar fractures as related to the age, carried out by the F-test, suggested a non-significant $(+)$ hyperbolic relationship.

The results of endodontic therapy of incisors and canines

Out of 36 incisor fractures, $25(69.4 \%)$ were treated endodontically. The remaining incisor fractures were extracted because of unfavourable prognosis (transverse fractures below the gingival margin, multiple root fractures).

The preoperative $\mathrm{x}$-ray examination showed no inflammatory periapical lesions in any of the cases. The period of endodontic treatment, starting from the occurrence of trauma, ranged from two days to three months. Standard root canal therapy was performed in all cases. The $\mathrm{x}$-ray examination half a year and one year after the therapy did not reveal any inflammation of periapical tissue in the treated teeth.

Out of 54 canine fractures, six $(11.1 \%)$ were extracted because of unfavorable prognosis. Seven of them (13\%) had no open pulp cavities. The majority (41 teeth - 75.9\%) of the open pulp cavity canine fractures showed necrotic dental pulp (28 teeth $-68.3 \%$ ).

The preoperative $\mathrm{x}$-ray examination revealed periapical lesions only in three cases. Two of them were also accompanied by a fistula. The owners were not aware of the time and cause of the trauma. In all cases, the standard root canal therapy yielded good therapeutic results.

Only eight dogs were presented within seven days after trauma. Out of this number, vital pulpotomy was performed in three dogs aged 10,15 and 17 months. Good therapeutic results were achieved with the youngest dog. Other teeth were matured at the time of trauma and the standard root canal therapy was the treatment of choice.

The postoperative x-ray examination performed in the same manner as that with incisors, did not reveal any periapical changes. 
The results of endodontic therapy in four maxillary premolars

No relationship between fractures of upper fourth premolars and the age and size of patients was found. These fractures were almost equally distributed among large and medium (+ small) breeds. They were diagnosed throughout the life of dogs up to 13 years of age.

The preoperative $\mathrm{x}$-ray examinations revealed periapical lesions, especially at the distal root. Out of 41 fractured fourth upper premolars, the distal roots alone were involved in 21 cases $(51.2 \%)$ and simultaneously with mesial roots in 11 cases $(26.8 \%)$. Periapical lesions involving only mesiobuccal roots were noticed in 5 cases $(12.2 \%)$.

The fractures of upper fourth premolars were complicated by swelling in 4 cases and fistula in 8 dogs. The standard root canal therapy of upper fourth premolars in comparison with incisors and canines was partialy complicated by inaccessible palatal root in smaller and older dogs. Out of 20 dogs of medium and small breeds, 8 palatal roots could not by accessed as a result of root canal calcification. All of them were dogs older than five years. Their palatal roots remained untreated.

Four out of 12 fractured teeth associated with swelling or fistula showed relapse problems within four-six weeks after the therapy. The repeated standard root canal therapy yielded good results in three cases.

The radiographic examination one year after the therapy showed no obvious changes in the size of periapical lesions in comparison with preoperative radiographs. However, the density of defects was higher, indicating healing processes.

Success of standard endodontic therapy in all teeth achieved $96.3 \%$ after the first endodontic intervention and another $2.8 \%$ cases were managed after the second endodontic treatment (together 99.1\%).

\section{Discussion}

Although human dentists Andreasen (1970) and Andreasen et al. (1989) reported that dental injuries occur at any age, they were more frequently observed in children 2-5year-old when they learn to walk and then to run. The second period is between ages 8 and 12 years, a period characterized by high degree of activity. In our experience, also the frontal teeth of dogs are most frequently affected at a young age. During the first two years of age, 61 dogs (43.9\%) suffered incisor, canine or premolar fractures. The majority of these fractures have been associated with the activity of dogs but the developmental stage of teeth also seems to influence the prevalence of tooth fractures. It is well known that teeth reach their maturity in the third year. An influence of teeth strength on the development of fractures is obvious also from our results which points to a marked decrease in the number of fractured frontal teeth in dogs older than 4 years. It should by emphasized that the activity of dogs did not decrease upon reaching this age. Normally, they retain full activity up to approximately 8 years of age. Our results confirm therefore an important influence of the amount of the produced dental tissue (secondary dentin) on the strength of teeth, particularly in young dogs. Bhaskar and Rappaport (1971) described low numbers of periapical lesions in incisor and canine fractures. Our observations showed the presence of periapical lesions in $3(3.3 \%)$ out of 90 incisor and canine fractures.

Le Brech et al. (1996) examined canine fractures in 142 army dogs. They investigated the prevalence of canine fractures in relation to the age of dogs. The following numbers of canine fractures were noticed: 2-4 years: 41 fractures, 5-7 years: 49 fractures, and over 7 years: 9 fractures. The authors also looked for the causes of canine fractures. In the majority of cases higher than 50\% loss of crown structure was observed. The causes of canine fractures were the following: training, behavioural problems (biting of cage bars). 
In our study, such a high prevalence of canine fractures with $50 \%$ loss of tooth structure was not observed. Out of 54 cases, 19 teeth (35.2\%) showed fracture line localized in the middle part and more apically. On the other hand, our sample included also other than military and police dogs.

The developmental stage of tooth strongly influences the prognosis. Eruption time is very critical for teeth.

Human dentist Arens (1977) claims that at the time of eruption human teeth are developed to $60-80 \%$ with regard to the quantity of dentin. Similar situation is in dogs. Two canine fractures at that age were characterized by excessive loss of unrestorable crown structure.

Holmstrom (1992) and Pavlica (1995) recommended vital pulpotomy in mature teeth up to 48 hours after the trauma. We prefer standard root canal therapy in these teeth for the following reasons:

- the tooth is mature and both types of endodontic treatment result in tooth crown pulp deprivation

- the preservation of root pulp has no significant influence on the health condition of the mature tooth over the life span of dogs

- the delay in vital pulpotomy increases the risk of therapeutic failure and necessity of standard root canal therapy.

In our experience, standard root canal therapy yields good therapeutic results. Some complications (relapse of fistula) occurred after the endodontic therapy of upper fourth premolars with fistulas. The surgical endodontic therapy was not used in any of the cases. Our results confirm those of Weine (1989) who claimed that the repeated use of standard root canal therapy, rather than surgical endodontic therapy, may yield good therapeutic results.

X-ray examinations of fractured teeth revealed different occurrence of periapical tooth lesions. Whereas incisors showed no periapical lesions and canines were involved only in $7.3 \%$ of them, the prevalence of periapical lesions in the four upper premolars reached $90.2 \%$ of all fractured teeth. The fistulas originated from distal root in all cases. The high prevalence of periapical lesions results probably from the position of the fourth maxillary premolars. These fractures are often overlooked by owners so that more complicated periapical lesions may develop contrary to frontal teeth.

In conclusion: The tooth fractures constitute a considerable fraction of tooth diseases. Nonsurgical endodontic treatment yields good results after the first therapy in majority of cases. Despite the occurrence of relapse, repeated standard root canal therapy is sufficiently successful. The higher number of complications in upper maxillary premolars is associated with advanced inflammation of periapical tissues resulting in the presence of much more necrotic dentin in apical delta. This necrotic dentin is a source of microbes initiating repeated infection in case of insufficient disinfection.

\section{Vyhodnotenie fraktúr zubov a endodoatickej terapie u psov}

Práca hodnotí výskyt zlomenín zubov u psov vo vztahu k veku, velkosti a v prípadoch známej anamnézy i k ich príčinám. Následne práca vyhodnocuje teapeutickú úspešnost̉ nechirurgickej endodontickej terapie. Analýza zahŕňa 139 zlomenín zubov ošetrených v priebehu štyroch rokov. Pred ošetrením boli dané zuby vyšetrené röntgenologicky s následnými dvomi vyšetreniami v polročných intervaloch.

Zlomeniny zubov sú druhým najčastejším zubným ochorením. Najčastejšie postihnutými zubami sú špičiaky $(38,8 \%)$, nasledované zlomeninami premolárov (31,1\%), rezákov $(25,9 \%)$ a molárov $(2,2 \%)$. Zlomeninami frontálnych zubov sú postihnuté predovšetkým velké plemená psov $(67,7$ \%), kým zlomeniny premolárov (zvlášt 108, 109) sú rovnomerne 
zastúpené u velkých a stredných zahŕňajúcich i malé plemená psov. Najvyšší výskyt zlomenín frontálnych zubov bol zistený do veku štyroch rokov $(87,7 \%)$. Štatistické vyhodnotenie F-testom potvrdilo signifikantnú hyperbolickú závislost (++) medzi výskytom zlomenín frontálnych zubov a vekom psov.

Výsledky nechirurgickej endodontickej terapie vykázali $100 \%$ úspešnost pri ošetrení rezákov a špičiakov. Periapikálne zápalové zmeny boli predoperačne zistené len u 32 $(4,5 \%)$ zubov z celkovo ošetrených 656 rezákov a špičiakov.

Zlomeniny maxilárnych štvrtých premolárov boli sprevádzané vysokým výskytom periapikálnych zmien $(90,2 \%)$ s najčastejším postihnutím distálneho koreňa $(75,6 \%)$. Výsledky endodontickej terapie boli úspešné u pacientov bez lokálnych zmien prejavujúcich sa prítomnostou opuchu a fistuly. U 12 zlomenín sprevádzaných týmito klinickými príznakmi (4 opuchy, 8 fistúl) došlo v 4 (33,3 \%) prípadoch k recidíve.

Výskyt zlomenín frontálnych zubov je viazaný predovšetkým na mladšie vekové kategórie psov s prevahou u velkých plemien sprevádzané zanedbatelným výskytom periapikálnych zmien. Naopak zlomeniny maxilárnych štvrtých premolárov sú rovnomerne zastúpené medzi rôznymi vekovými kategóriami a velkostami psov. Napriek značnému výskytu periapikálnych zápalových zmien dosiahnuté výsledky štandardnej endodontickej terapie boli dobré a opakované ošetrenie recidív viedlo prevažne k úspešnému výsledku.

\section{References}

ANDREASEN, F. M., ANDREASEN, J. O., BAYER, T. 1989: Prognosis of root fractures permanent incisors: prediction of healing modalities. Endod. Dent. Traumatol. 5: 11-13

ANDREASEN, J. O. 1970: Etiology and pathogenesis of traumatic dental injuries: clinical study of 1298 cases. Scand. J. Dent. Res. 78: 329-334

ARENS, D. E. 1977: Apexification, pulp capping and pulpotomy. In: Clinical Dentistry, 4, Harper and Row, Maryland,.215 p.

BHASKAR, S. N., RAPPAPORT, H. M. 1971: Histologic evaluation of endodontic procedures in dogs. Oral Surg. 31: $526-531$

EISENMENGER, E., ZETNER, K 1985: Tooth fracture and alveolar fracture. In: Veterinary dentistry, Lea and Febiger, Philadelphia, 245 p.

FRANCESCHINI, G. 1974: Traitement des fistules dentaires chez le chien par obturation des canaux (fistules sousorbitaire et gingivale) Recueil de Medicine Vétérinaire 8: 675-684

HARVEY, C. E., EMILY, P. 1993: Small animal dentistry. Mosby - Year Book, St. Louis, 413 p.

HOLMBERG, D. L. 1979: Abscessation of the mandibular carnassial tooth in the dog. J. Am. Anim. Hosp. Assoc. 15: $347-350$

HOLMSTROM, S. E. 1992: Endodontics. In: Veterinary dental techniques. W.B. Saunders Co., Philadelphia, 207 p.

LE BRECH, CH., HAMEL, L., Le NIHOUANNEN, J. C., DACULSI, G.1996: Étude épidémiologique des fractures des crocs chez le chien militaire. Revue Méd. Vet. 147: 389-402

NEUMAN, W. 1988: Rekonstruktion frakturierter Zähne beim Hund mit verschiedenen Kunststoffmaterialen. Praktische Tierartzt. II: 26-30

PAVLICA, Z. 1995: Zobna pulpa pri psu in njeno radikalno zdravljenje. Vet. Nov. 21: 118-123

ROSSMAN, L. E., ROSSMAN, S. R., GARBER, D. A.1982.: The endodontic periodontic fistula. Oral. Surg., Oral. med., Oral. pathol. 53: 78-85

WEINE, F. S.: Endodontic therapy. 4ht ed., Mosby, St. Louis, 1989, 63 p. 